The results show that indirect selection (effect of fitness and positive effect on the selection index) will rise the gene frequency for hypersensitivity to halothane, as long as no direct selection is applied against the trait.

It is estimated that the gene frequency without direct selection in the Dutch Landrace will increase within 5 generations from 0.47 to about 0.65 and within ro generations to 0.83 .

In order to select against hypersensitivity to halothane, 3 alternatives are discussed: building in the trait in a selection index, direct selection by excluding all positive boars and possibly also gilts from performance testing, and the set-up of lines of homozygous negative pigs.

\title{
CONSEQUENCES OF SELECTION FOR EGG WEIGHT ON HATCHABILITY
}

F. PIRCHNER, R. MERGI, and D. K. FLOCK

Lehrstuhl für Tierzucht der Technischen Universität München

D8050 Freising-Weihenstephan B.R.D. und Lohmann Tierzucht GmbH, Cuxhaven B.R.D.

Genetic correlations were estimated between hatchability traits of purebreds and egg number and egg weight of crossbreds. While hatchability and egg number were positivly correlated genetically in one strain, essentially no correlation existed in the other. Correlations pertaining to egg weight were unfavorable in both strains but more so in one. Correlations with number of saleable chicks were positive for egg number and negative for egg weight. Selection according to a restricted selection index egg number and egg weight (this to be held constant) should impair hatchability in one strain.

\section{BezIEHUNGEN ZWISChEN DEN EIGENLEISTUNGSERGEBNISSEN VON PRÜFBULI,EN UND DEN ABKALBEERGEBNISSEN AUS DEM TESTEINSATZ}

\section{G. AVERDUNK, K. OSTERKORN, H. KRÄUSSLICH und A. GOTTSCHALK \\ Bayerischen Landesanstalt fur Tierzucht, \\ Grub B.R.D. und Lehrstuhl für Tierzucht der Universität Munchen, München B.R.D.}

Am Material der Fleckvieh-Eigenleistungsbullen in Bayern wurden die Beziehungen zwischen Wachstumsdaten und Körpermaßen von Bullen und den Abkalbeergebnissen der von ihnen gezeugten Kälber untersucht, wobei sowohl der Anteil and Totgeburten als auch der mit tierärztlicher Hilfe und die Trächtigkeitsdauer herangezogen wurde. Die Beziehungen zwischen den ELPDaten und den Abkalbeergebnissen sind alle positiv, wobei kein Körpermaß besonders heraussticht. Der Anteil tierärztlicher Hilfe ist mit den ELP-Daten enger korreliert als derjenige der Totgeburten, während die Trächtigkeitsdauer weniger einheitliche Ergebnisse zeigte. Die Korrelationen waren für männliche Kälber deutlich höher.

Die Heritabilitätsschätzweite für Totgeburten lagen im Bereich von 0.005 bis 0.022, für tierärztliche Hilfe zwischen 0.008 und 0.028 . Die genetischen Korrelationen zwischen dem $4^{20}$ Tage-Gewicht und den Abkalbeergebnissen betrugen $+0.40 \mathrm{bzw}$. +0.43 , während die Zunahme in der Prüfperiode vom I $z$. - 420. Tag Werte von $+0.2 \mathrm{I} \mathrm{bzw.}+0.3 \mathrm{I}$ zeigte. Dieser Unterschied deutet daraufhin, daß das Geburtsgewicht des Vaters die Hauptursache für die hohen genetischen Korrelationen ist. Deshalb sollte das Schwergewicht der Selektion auf die Zunahme in der Prüfperiode bzw. einem Index unter Berücksichtigung des Geburtsgewichtes erfolgen, um negative Auswirkungen auf das Abkalbeverhalten zu vermeiden.

\section{DIRECT AND CORRELATED EFFECTS OF VARIOUS SELECTION STRATEGIES IN PERFORMANCE TESTS OF BULLS}

\section{B. BECH-ANDERSEN}

National Institute of Animal Science, Dep. of Cattle and Sheep Experiments, Rolighedsvej 25, I958 Copenhagen V., Denmark

The investigation described in this paper is based on 2,330 veal calves and young bulls after 136 sires of the breeds Red Danish, Black Pied Danish and Danish Red and White. For these animals information on gestation length, birth weight, daily gain, feed intake and carcass compo- 